\title{
Smallholders' willingness to pay for dura marking oil palm seeds
}

\author{
Diana Chalil ${ }^{1}$, Mohammad Basyuni ${ }^{2, *}$, Riantri Barus ${ }^{1}$, and Lollie AP Putri ${ }^{3}$ \\ ${ }^{1}$ Department of Agribusiness, Faculty of Agriculture, Universitas Sumatera Utara, Medan, North \\ Sumatera 20155, Indonesia \\ ${ }^{2}$ Department of Forestry, Faculty of Forestry, Universitas Sumatera Utara, Jl. Tri Dharma Ujung No. 1 \\ Medan, North Sumatera 20155, Indonesia \\ ${ }^{3}$ Department of Agrotechnology, Faculty of Agriculture, Universitas Sumatera Utara, Medan, North \\ Sumatera 20155, Indonesia
}

\begin{abstract}
In 2018, around 4 million ha of oil palm smallholdings need to be replanted. Indonesia could utilize this moment to improve smallholdings' productivity by ensuring the usage of good quality seeds. For the industry, Dura is considered as bad seeds as its thick shells can damage the machine and the oil content is low. Therefore, most mills do not want to buy it, hence the selling price is low. In fact, most smallholdings' use uncertified seedlings that include many contaminated Dura. Unfortunately, smallholders can only detect this 3 years after the planting and spending a considerable amount of production costs. Actually, to avoid the unnecessary loss a Dura marking technique can be applied to the oil palm seeds. However, most smallholders are unlikely consider Dura usage as an important issue due to the higher weight and higher sales revenue. This study is conducted to analyse smallholders' willingness to pay (WTP) for seed marking service. Data is collected from 60 independent smallholders in Labuhan Batu Utara, which mostly use the uncertified seedlings. The willingness to pay is measured with Conjectural Variations Approach, revealing $71 \%$ of the respondents are willing to pay the Dura seed marking service, although still with a minimum level of WTP. Pearson Chi Square Correlation Test shows that the WTP for Dura Marking Service is only significantly correlated with the smallholders' knowledge and perception, but not with their land size and experience. Based on the results, a number of policy implication are included.
\end{abstract}

\section{Background}

Oil palm growers in Indonesia can be differentiated into 3 groups, namely state companies, private companies and smallholders. Smallholdings are the most recently developed group, just started in 1979 with 3,125 ha, but exponentially grew to 4.7 million ha in 2017 or around $38.64 \%$ of the total Indonesian oil palm areas [1]. Initially smallholdings were developed within government program as plasma of big companies. Successfully increasing the schemed smallholders' income, many independent smallholders then started developing

\footnotetext{
* Corresponding author: m.basyuni@usu.ac.id
} 
their oil palm plantations. However, without big companies' supervision, most of the independent smallholdings did not apply the recommended cultivation techniques, including the usage of good quality seeds. In fact, the usage of counterfeit seed tends to be particular constraint for oil palm smallholders all over the world [2]. There are 3 types of oil palm seeds, namely Dura, Pisifera and Tenera. Tenera is considered as the high quality seeds, thus determined as the certified seed, which has higher productivity and oil content. It is the cross type from Dura and Pisifera. In 2012 previous study found in North Sumatra Province, $80.28 \%$ of independent smallholders used the uncertified and illegitimate seedlings [3]. In 2015 similar condition still appeared, in which $60 \%$ of smallholdings in Sumatra used uncertified and illegitimate seedlings. Among them $90 \%$ are independent smallholders [4]. In addition, [5] found that the smaller the smallholding area, the less Tenera trees are found. Dividing 243 smallholdings' size into small, medium and large group, each has $12 \%, 24 \%$ and $49 \%$ Tenera of the total seeds, respectively. As a result, independent smallholdings' productivity appeared to be the lowest comparing to the schemed smallholdings, state and private plantations, which are 2.92, 3.52 and 3.52 ton $\mathrm{CPO} / \mathrm{ha} /$ year, respectively.

On average Dura productivity and oil content are 10-12 ton FFB/ha/year and 12-18\%, respectively (Lubis 2004 in [4] [6]). Although with good treatment, the productivity of the uncertified seedlings could be improved, but their maximum productivity are only $60-70 \%$ of those the certified optimal productivity. With a significant smallholdings' share in the Indonesia oil palm plantations, such a condition makes the average of Indonesia's oil palm plantation productivity only 3.19 ton $\mathrm{CPO} / \mathrm{ha} /$ year, while the potential is $8-9$ ton $\mathrm{CPO} /$ ha/year [4]. The low productivity increases the average cost, which at the end could reduce the Indonesian palm oil competitiveness. However, as the average of oil palm productivity 5 times higher than other vegetable oil productivities, currently palm oil prices are still the lowest and recorded as the highest traded vegetable oil in the world.

The main factor for smallholders not using the certified seeds is the big price difference between the certified and non-certified. In fact, seeds' costs in only $3 \%$ of the total production costs, while the impact will take place for the whole 25 years of the production period. [7] predicted that the usage of high quality seeds and improving the agricultural practice could increase oil palm smallholding yield around $26 \%$. Another reason is the lack of knowledge among smallholders, which presumed that all Tenera trees will always produce Tenera FFB [8][9]. In fact, the crossed of these seeds will produce around 25\% Dura 50\% Tenera, and 25\% Pisifera [6][10][11]. Unfortunately, smallholders can only detect Dura from the FFB, which first harvest is 3 until 4 years after the planting. If smallholders do not have to wait until the early fruit to marking the good seeds, the unnecessary loss could be avoided.

On average, the world palm oil production is around 3 ton $\mathrm{CPO} / \mathrm{ha} / \mathrm{year}$, while the maximum could reach 12 ton $\mathrm{CPO} /$ ha year. Theoretically the potential could even reach 18.5 ton $\mathrm{CPO} /$ ha/year [7]. This means, closing all production gaps could increase the world production without further increasing land clearing. However, most smallholders do not concern this as an important issue and will to expend some extra costs. This study is conducted to analyze smallholders' willingness to pay (WTP) for seed marking service. The results are expected to give some information for policy makers in improving oil palm smallholdings' performance.

\section{Method}

This is study is conducted in Kabupaten Labuhanbatu Utara, North Sumatra Province, which is one of the oil palm plantation centers. Primary data is collected from 60 independent smallholder samples, which are selected with purposive sampling method. 
There are 2 types of Willingness to Pay (WTP) measured, namely WTP for using legitimate seed and WTP for Dura marking. WTP is measured with the Conjectural Variation (CV) approach where samples were directly asked about their WTP for using the seed marking service and for buying certified/legitimate seeds. WTP were revealed using two types of questionnaire, namely the open-ended and the bidding game approach of maximum amount that samples' would be willing to pay. The amount is divided into 6 classes, which are 0 for those who do not want the service, WTP $<$ IDR10,000 (USD0.72), IDR10,000 (USD0.72) $<$ WTP $<$ IDR20,000 (USD1,45), IDR20,000 (USD1,45) < WTP < IDR30,000 (USD2.17), IDR30,000 (USD2.17) < WTP < IDR40,000 (IDR2.89), and WTP > IDR40,000 (IDR2.89). Then the 4 possible correlated factors with the Dura marking WTP, namely land size, experience, knowledge and perception were tested using the Pearson Chi-Square cross tabulations. Land size is measured in hectare. Experience refers to samples' year of working at or managing oil palm plantation. Knowledge is measured with scores on smallholders' awareness about seed and seedling types, characteristics and benefit of not using Dura. Perception refers to samples' view about the benefit on using Dura marking service.

\section{Results and discussion}

The survey shows that $89 \%$ of the respondents can differentiate Dura and Tenera, which all know from the shell size of their FFB. This means that respondents revealed it after the first harvest, which is 3 to 4 years after planting. These respondents know that Dura is heavier, while Tenera has higher oil content. However, only 5\% agree that Tenera is beneficial for both smallholders and mills, while the rest prefer Dura because all of them sell their FFB to traders that do not grade the FFB. The Pearson Chi Square value of 3.418 shows that no significant difference between the average productivity of smallholdings using the certified and uncertified seeds. On average both receive yield in between 1 to 2 ton FFB/ha/month. Similarly, The Pearson Chi Square of 0.804 also shows no significant income difference between smallholders that use the certified and uncertified seeds. However $29 \%$ of the certified have enjoyed more than IDR2,000,000 (USD144.59) per month, while only 15\% of the uncertified receive the similar income amount.

Among the samples, $75 \%$ suggest Dura is more profitable than Tenera. Therefore, most (77.97\%) smallholders still use the uncertified/illegitimate seedlings, mainly because the price is significantly lower than the certified, which are IDR 15,000 (IDR1.08) and IDR 40,000 (IDR2.89), respectively. The study shows that all respondents are willing to pay the certified seedlings, but only 29\% with WTP IDR 25,000 (USD1.81) or more for the average price difference between the certified and non-certified seedlings. This is in accordance with the fact that $77.97 \%$ of the samples use uncertified seedlings, as on average the price difference between the uncertified and certified seedlings is about IDR25,000 (USD1.81). More than $80 \%$ of the smallholders got the seedlings from other smallholders and illegitimate traders. Only $16.67 \%$ of them bought the seedlings from palm oil companies, input production shops and nurseries. Such a condition indicates that smallholders and illegitimate breeders still have important roles in supplying seeds and seedlings for smallholders. Therefore, Indonesian Oil Palm Research (IOPRI) includes them in their mentoring and coaching program, so that smallholders could obtain good quality seed and seedlings [6].

In contrast with the WTP for the certified seedlings, $29 \%$ of the samples do not willing to pay for the Dura marking service. In general, smallholders WTP for certified seeds are greater than their WTP for Dura marking service. The complete comparison of the WTP for getting certified seedlings and WTO for having marking service can be seen in Figure 1. 


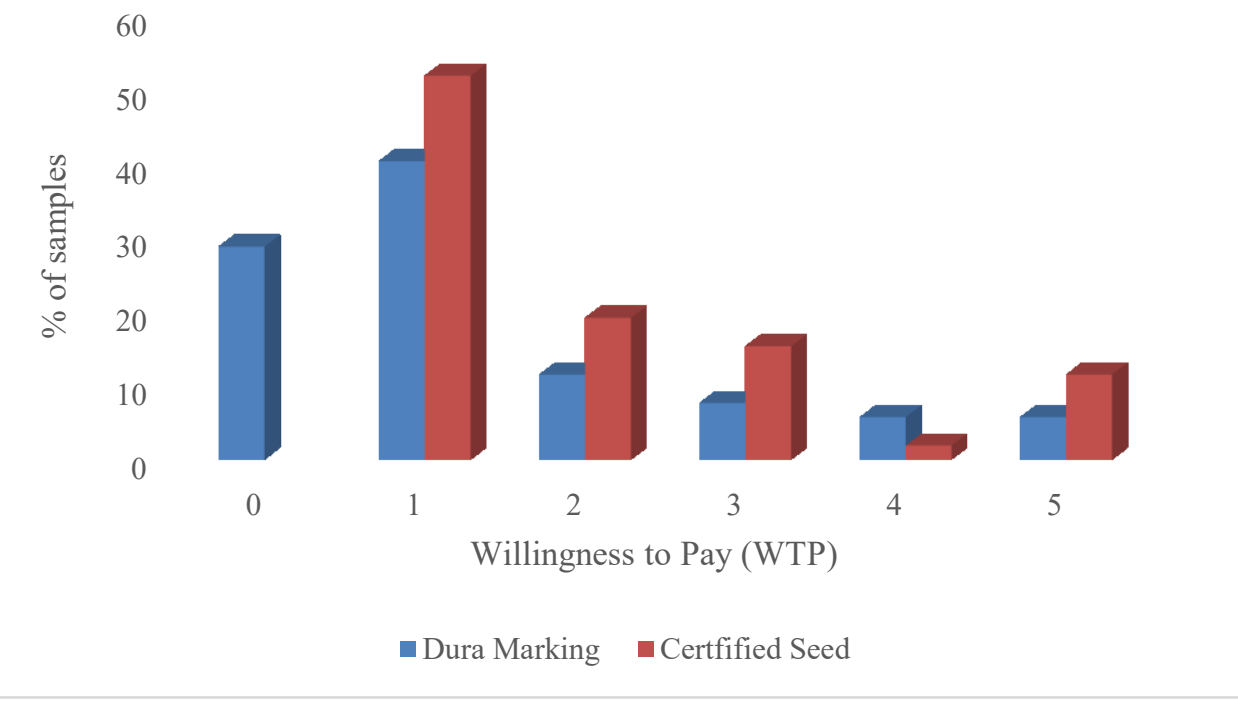

Fig. 1. Sample distribution based on 6 classes of WTP for certified seeds and dura marking service.

Figure 1 shows that for Dura marking service, there are still $29 \%$ of the sample have 0 score, indicating their unwillingness to pay for the service. This might indicates the smallholders' view about Dura, which is not the best seeds but still beneficial for its heavier weight. In other words, these smallholders do not in purpose pay for the Dura but they would be happy to enjoy the benefit if coincidentally get the Dura. Therefore, they do not want any extra expenditure to get the marking service. However, $71 \%$ of the respondents are already willing to pay the Dura marking service, although most (40\%) with minimum amount (maximum IDR10,000 or USD0.72), and only $3 \%$ will to pay the maximum amount (IDR40,000 or USD2.89).

Table 1. Compare means test results between WTP for dura marking service and possible correlating factors.

\begin{tabular}{|c|c|c|c|c|}
\hline \multirow{2}{*}{ Description } & \multirow{2}{*}{ Range } & \multirow{2}{*}{ Average } & \multicolumn{2}{|c|}{ Pearson Chi-Square } \\
\cline { 3 - 5 } & & & Value & Significance \\
\hline Land Size & $1.00-5.50$ & 2.22 & 47.074 & 0.206 \\
\hline Experience & $1.00-56.00$ & 16.00 & 125.092 & 0.245 \\
\hline Knowledge & $0.00-4.00$ & 1.79 & 31.770 & $0.046^{*}$ \\
\hline Perception & $0.00-0.10$ & 0.73 & 17.752 & $0.003^{* *}$ \\
\hline
\end{tabular}

Table 1 shows that land size and experience are not correlated with the smallholders' WTP for Dura marking service. With the range of 1.00 ha to 5.50 ha and $92.31 \%$ are less than 4 ha, most of them sell their FFB to village traders that did not differentiate the Dura and Tenera FFB. Therefore, land size is not significantly correlated with the WTP for marking service. Similarly, without involving sufficient learning process related to Dura seed, smallholders' experience is also not correlated to their WTP. In contrast, knowledge and perception are significantly correlated with the smallholders' WTP for the marking service. The smallholders' knowledge are mostly obtained from parents and friends (around $70 \%$ ), $25 \%$ autodidact, and only $3.45 \%$ get it from palm oil companies through trainings or experience as the companies' workers. None got the information from extension workers. In such condition, information about Dura might be unclear and incomplete, thus might 
partly explain the zero and low score of their WTP for the marking service. Smallholders rarely receive complete knowledge about good seeds and seedlings, and Good Agricultural Practice. Some smallholders have known some indications of the bad seedlings, but only few of them understand various types of the bad seedlings. Most obtain comprehensive seedling knowledge through field trips to pre-nurseries and nurseries. Most smallholders still assume that certified seedlings are expensive, until they know the seedling expenditure share to the total production costs. They also know that Tenera has higher productivity, but most assume that Dura productivity could be improved with good fertilization. None understood that even with complete recommended fertilization, uncertified seedlings could only reach $70 \%$ of the certified seedlings productivity. Instead their willingness to pay, $70 \%$ of the samples are willing to bring the marking test material if the marking service is provided in the same district, otherwise only $30 \%$ are willing to do so. IOPRI provided mobile seedlings shop to improve smallholders' access on good quality seedlings. They periodically visit 8 smallholding centers in Sumatra every 3-6 months, and has distribute 1,692,650 seeds from 2011-2015. In fact, after the visit, some smallholders even directly come to IOPRI office in Medan to buy certified seedlings [6].

\section{Policy implications}

Improving the usage of good quality seeds and seedlings is important among smallholders. Currently, most smallholders still use illegitimate seedlings with Dura dominance, thus having low FFB productivity with low oil content. Most smallholders know the Tenera quality, but still many prefer Dura due to its heavier weight. In open market Dura and Tenera FFB selling price is not differentiated. In government FFB selling price, oil content has been concluded as one of measurement component. However, this price only applies to schemed smallholders. In fact, independent smallholders share is increasing. Therefore, similar selling price components also need to be applied in open market, which can be interfered through the Plantation Directorate General. On the other hand, similar program of the certified seeds and seedlings could be modified for the Dura marking service. This is not only limited for smallholders as consumers but also small scale oil palm nurseries, which mostly supply seeds for smallholders.

\section{Acknowledgements}

This work was supported in part by a Penelitian Strategis Nasional Institusi (PSN Institusi 2018) from the Directorate for Research and Community Service, Ministry of Research, Technology and Higher Education, Republic of Indonesia.

\section{References}

1. Tree Crop Estate Statistics of Indonesia 2015-2017: Palm Oil, Secretariate of Directorate General of Estate Crops, Directorate General of Estate Crops, Ministry of Agriculture

2. L.S. Woittieza, M.T. Van Wijk, M. Slingerlanda, M. van Noordwijk, K.E. Giller. Yield gaps in oil palm: A quantitative review of contributing factors. European Journal of Agronomy 83, (2017)

3. D. Chalil, Z. Zein Analisis implemetasi kesepakatan RSPO pada perkebunan sawit rakyat. Research Report. National Strategic Fund (Hibah Strategis Nasional), 
Direktorat Jenderal Pendidikan Tinggi, Kementerian Pendidikan dan Kebudayaan. (2012)

4. M.A. Agustira, R. Amalia, R. Nurkhoiry. Program sawit untuk rakyat (Prowitra) sebagai upaya peningkatan produktivitas, pemberdayaan, keberlanjutan, dan kesejahteraan pekebun kelapa sawit rakyat. Prosiding Seminar Nasional "Perlindungan dan Pemberdayaan Pertanian dalam Rangka Pencapaian Kemandirian Pangan Nasional dan Peningkatan Kesejahteraan Petani". Pusat Sosial Ekonomi dan Kebijakan Pertanian, Kementerian Pertanian. (2015)

5. I. Jelsma, G.C. Schoneveld. Mewujudkan petani kecil sawit mandiri yang lebih produktif dan berkelanjutan di indonesia pandangan dari pengembangan tipologi petani kecil, Pusat Penelitian Kehutanan Internasional (CIFOR), Universitas Utrecht. Working Paper 217, (2016)

6. K. Setiawan. Pemuliaan kelapa sawit untuk produksi benih unggul: tanaman pendek, kompak, dan minyak tak jenuh tinggi (Plantaxia, 2017)

7. T. Soliman, F.K.S. Lim, J.S.H. Lee, L.R. Carrasco. Closing oil palm yield gaps among Indonesian smallholders through industry schemes, pruning, weeding and improved seeds. Royal Society Open Science Aug 3,8 (2016)

8. E. Akpo, P.V. Vissoh, R.C. Tossou, T. Crane, D.K. Kossou, P. Richards. T.-J. Stomph, P.C. Struik. A participatory diagnostic study of the oil palm (Elaeis guineensis) seed system in Benin. Wageningen Journal of Life Sciences 60-63, (2012)

9. Aprizal. Analisis daya saing usahatani kelapa sawit Kabupaten Mukomuko. Tesis, Program Studi Magister Agribisnis, Fakultas Pertanian, Universitas Bengkulu. (2013)

10. M. Basyuni, N. Amri, L.A.P. Putri, I. Syahputra, D. Arifiyanto. Characteristics of Fresh fruit bunch yield and the physicochemical qualities of palm oil during storage in North Sumatra, Indonesia. Indonesian Journal of Chemistry 17, 2 (2017)

11. M. Basyuni, R. Wati, I. Deni, A.R. Tia, B. Slamet, E.S. Siregar, I. Syahputra. Cluster analysis of polyisoprenoid in oil palm (Elaeis guineensis) leaves in different land-uses to find the possible cause of yield gap from planting materials. Biodiversitas 19, 4 (2018) 